\title{
Оценка на устойчивость казахстанских образцов пшеницы к патогену Pyrenophora Tritici-repentis
}

Кумарбаева M.T. ${ }^{1,2 *}$, м.н.с., РhD докторант; Кохметова А.M. ${ }^{1,2}$, д.б.н., профессор; Коваленко Н.М. ${ }^{3}$, к.б.н., с.н.с.

${ }^{1}$ Казахский Наџиональный Аграрный Университет, Алматы, Казахстан; ${ }^{2}$ Институт Биологии и Биотехнологии Растений, Алматы, Казахстан; ${ }^{3}$ Всероссийский научно-исследовательский институт защить растений, Санкт-Петербург, Россия.

*e-mail:madina_kumar90@mail.ru

Pyrenophora tritici-repentis является важным листовым заболеванием пшеницы. Целью исследований является в лабораторных условиях идентифицировать и отобрать перспективные линии пшеницы устойчивых $\kappa$ пиренофорозу P. tritici-repentis. В качестве объектов исследований была создана коллекиия включающая перспективные линии и сорта казахстанской селекиии. В результате исследований было отобрано 17 перспективных линий и 5 казахстанских сортов (Dana, Daulet, Diana, Dinara, Krasnovodopadskaya 210), включаюшие устойчивость к Ptr ToxA и Pt. ToxB, а также полевую устойчивость. Отобранный перспективный материал используется в программах селекции пшеницы, на повышение устойчивости к пиренофорозу.

Ключевые слова: пшений, популяция Pуrenophora tritici-repentis, устойчивость, пиренофороз.

\section{Assessment of the resistance of Kazakh wheat samples to the pathogen Pyrenophora tritici-repentis}

Kumarbayeva Madina Talgarovna, ${ }^{1,2}$, Kokhmetova Alma Myrzabekovna, ${ }^{1,2}$, Kovalenko Nadezhda Mikhailovna ${ }^{3}$.

${ }^{1}$ Kazakh National Agrarian University, Almaty, Republic of Kazakhstan, madina_kumar90@mail.ru

${ }^{2}$ Institute of Plant Biology and Biotechnology, Almaty, Republic of Kazakhstan, ${ }^{3}$ All-Russian Research Institute of Plant Protection, Saint-Petersburg, Russia

Pyrenophora tritici-repentis of wheat is an important leaf disease of wheat. The aim of the research is to identify and select promising lines of wheat resistant to tan spot P. tritici-repentis in the laboratory. As objects of research, a collection was created that includes promising lines and cultivars of Kazakh selection. As a result of the research, 17 promising lines and 5 Kazakh cultivars (Dana, Daulet, Diana, Dinara, Krasnovodopadskaya 210) were selected, including resistance to PTR ToxA and PTR ToxB and field resistance. Selected a promising material used in breeding programs of wheat to increase resistance to tan spot. 
Key words: wheat, population of Pyrenophora tritici-repentis, isolates, resistance, tan spot.

В последнее годы в последствии измениения климата, минимальной обработкти почвы и нарушения севооборатов приводит к видовым изменениям возбудителей особо ценных сельскохозяйственных культур. Пиренофороз встречается на пшенице и некоторых дикорастущих злаках (Agropyron, Bromus, Agrostis, Avena, Hordeum, Lollium, Festuca, Setaria, Stipa и другие) [1]. На ржи и ячмене отмечается редко, овес к P. tritici-repentis устойчив. В период вегетации возбудитель распространяется конидиями воздушно-капельным путем. Зимует гриб возбудителя на пожнивных остатках, семенах. На перезимовавших листьях и стеблях образуется сумчатая стадия возбудителя в черных псевдотециях. Осуществляют заражение растений весной и являются дополнительным источником инфекции. В исследованиях Л. Ламари с соавторами, отмечали два симптома, связанные с пиренофорозом, таких как некроз и хлороз. Некротические пятна окрашиваются в желто-коричневый цвет, тогда как хлоротичные пятка появляются в результате постепенного пожелтения ткани [2]. Изоляты P. tritici-repentis охарактерезованы по их способности вызывать некрозы и (или) хлорозы. Lamari и Bernier (1989a) классифицировали 4 патотипа гриба Ptr: nec ${ }^{+} \mathrm{chl}^{+}$вызывает некроз и хлороз; nec $^{+} \mathrm{chl}^{-}-$вызывает только некроз; nec $\mathrm{chl}^{+}$вызывает только хлороз; nec $\mathrm{chl}^{-}-$не вызывает ни некроз, ни хлороз [3]. Кроме листьев порожает стебли пшеницы, в последствии образуются серокоричневые и темно-бурые полоски. В 2016 году А. Кохметова с соавторами изучила расовый состав и вирулентность изолятов P. tritici-repentis в Казахстане и на Северо-Кавказском регионе России. Показано что в Казахстане, доминирующими являются расы 1 и 8 , раса 8 обнаружена впервые в Казахстане [4].

Исследования проводили на коллекции из 93 образцов мягкой пшеницы Triticum aestivum, включающей перспективные линии и сорта казахстанской селекции. Наиболее подходящий метод лабораторной оценки устойчивости к пиренофорозу является инокуляция отрезков листьев, помещенных в раствор бензимидазола [1]. Оценку на устойчивость проводили на стадии пяти листьев, растения выращивали на смоченной вате в кюветах (рисунок). Отрезки 10-дневных проростков пшеницы длиной 3-4 см раскладывают на стекло, заранее обернутое фильтровальной бумагой, смоченной $0,004 \%$ водным раствором бензимидазола. Для приготовления суспензии споры гриба собираем шпателем с поверхности питательной среды, добавляем детергент Твин-80 (0,0001 \%), затем суспензию фильтруем через металлическое ситечко для отделения фрагментов мицелия. Инокуляция отрезков листьев проведена способом опрыскивания суспензией конидий из пульверизатора. Для инокуляции была использована суспензия с концентрацией 3-5 тыс. спор конидиеспор на мл. Кюветы с инфекционным материалом 
плотно обертываем полиэтиленовой пленкой и выдерживаем в течение 24 часов в темноте. После суток темноты кювету помещаем в светоустановку с флуоресцентными лампами ЛБ-40 при температуре $22-24{ }^{\circ} \mathrm{C}$. Оценку реакции проростков на устойчивость к пиренофорозу суспензией $P$. triticirepentis проводили на седьмые сутки по разработанной шкале Михайловой и др. [1]. Результаты лабораторной оценки на устойчивость к пиренофорозу приведены в таблице.

Таблица - Лабораторная оценка казахстанских образцов на устойчивость к P. tritici-repentis

\begin{tabular}{|c|c|c|c|c|c|}
\hline $\begin{array}{l}\text { Название } \\
\text { образцов }\end{array}$ & $\begin{array}{c}\text { Оценка } \\
\text { устойчивости } \\
\text { на ТохА Ка- } \\
\text { захстанская } \\
\text { популяция } \\
\end{array}$ & $\begin{array}{c}\text { Фенотип } \\
\text { устойчивост } \\
\text { и пшеницы }\end{array}$ & $\begin{array}{c}\text { Оценка } \\
\text { устойчивости } \\
\text { на ТохВ Гре- } \\
\text { ческая попу- } \\
\text { ляция } \\
\end{array}$ & $\begin{array}{c}\text { Фенотип } \\
\text { устойчив } \\
\text { ости } \\
\text { пшеницы }\end{array}$ & $\begin{array}{c}\text { Полевая } \\
\text { оценка к } \\
\text { PTR, } \\
2019\end{array}$ \\
\hline GF_1_CP & $1 / 1$ & $\mathrm{R}$ & $1 / 0$ & $\mathrm{R}$ & 10 \\
\hline GF_5_CP & $1 / 1$ & $\mathrm{R}$ & $1 / 1$ & $\mathrm{R}$ & 5 \\
\hline GF 7 CP & $1 / 1$ & $\mathrm{R}$ & $0 / 1$ & $\mathrm{R}$ & 5 \\
\hline GF $11 \mathrm{CP}$ & $1 / 1$ & $\mathrm{R}$ & $1 / 1$ & $\mathrm{R}$ & 5 \\
\hline GF_13_CP & $1 / 1$ & $\mathrm{R}$ & $1 / 1$ & $\mathrm{R}$ & 10 \\
\hline GF 23_CP & $1 / 0$ & $\mathrm{R}$ & $1 / 0$ & $\mathrm{R}$ & 0 \\
\hline 10204_1_KSI & $2 / 1$ & MR & $1 / 1$ & $\mathrm{R}$ & 0 \\
\hline 10204_2_KSI & $2 / 1$ & MR & $2 / 2$ & MR & 0 \\
\hline 10204_3_KSI & $1 / 1$ & $\mathrm{R}$ & $1 / 1$ & $\mathrm{R}$ & 0 \\
\hline $102051 \mathrm{KSI}$ & $1 / 2$ & MR & $1 / 1$ & $\mathrm{R}$ & 5 \\
\hline 102052 KSI & $1 / 2$ & MR & $1 / 1$ & $\mathrm{R}$ & 5 \\
\hline 601 SP2 & $1 / 1$ & $\mathrm{R}$ & $1 / 2$ & MR & 5 \\
\hline 620 SP2 & $1 / 1$ & $\mathrm{R}$ & $1 / 1$ & $\mathrm{R}$ & 5 \\
\hline 621_SP2 & $1 / 1$ & $\mathrm{R}$ & $2 / 2$ & MR & 10 \\
\hline 624_SP2 & $1 / 0$ & $\mathrm{R}$ & $1 / 2$ & MR & 10 \\
\hline 630_SP2 & $1 / 0$ & $\mathrm{R}$ & $2 / 0$ & MR & 0 \\
\hline 640_SP2 & $1 / 0$ & $\mathrm{R}$ & $1 / 1$ & $\mathrm{R}$ & 0 \\
\hline Dana & $2 / 2$ & MR & $1 / 2$ & MR & 5 \\
\hline Daulet & $1 / 2$ & MR & $1 / 2$ & MR & 0 \\
\hline Diana & $2 / 2$ & MR & $1 / 2$ & MR & 5 \\
\hline Dinara & $2 / 1$ & MR & $1 / 1$ & $\mathrm{R}$ & 5 \\
\hline $\begin{array}{l}\text { Krasnovodopadska } \\
\text { ya } 210\end{array}$ & $1 / 1$ & $\mathrm{R}$ & $1 / 1$ & $\mathrm{R}$ & 5 \\
\hline
\end{tabular}

Примечание: над чертой - балл развития некроза, под чертой - балл развития хлороза.

В лабораторных условиях (ВИЗР, СПб, Россия) была проведена инокуляция и оценка 93 образцов пшеницы из казахстанской коллекции. Заражение было проведено популяцией из коллекции ВИЗР (казахстанская популяция Ptr ToxA и греческая популяция Ptr ToxB). По результатам оценка устойчивости на Ptr ToxA казахстанскую популяцию было выделено 18 перспективных линий (19,35 \%) устойчивых (R) с оценкой $1 / 0,1 / 1.39$ образцов (42 \%) показали среднеустойчивую реакцию (MR) с оценкой по некроз/хлорозу 1/2, 2/1, 2/2. 
Восприимчивый тип реакции (MS) с оценкой $3 / 2,3 / 3,3 / 4$ было отмечено у 34 образцов, что составляет 36,55 \% от общего числа изученного материала. Два образца показали высокую восприимчивость (HS) с оценкой по некроз/хлорозу 4/4 (610_SP2, 615_SP2). В результаты оценки на греческую популяцию Ptr ToxB выявлено 39 образцов (42 \%) с устойчивым типом реакции (R). Среднеустойчивый тип реакции (MR) было установлено у 40 образцов, что составляет 43 \%. Двенадцать перспективных линии проявили себя как средневосприимчивыми (MS) с типом реакции 2/3. При оценке на устойчивость к $P \operatorname{tr} T$ oxB восприимчивый тип (S) реакции с оценкой $3 / 3$ проявили два образца (GF_4_CP, 639_SP2).

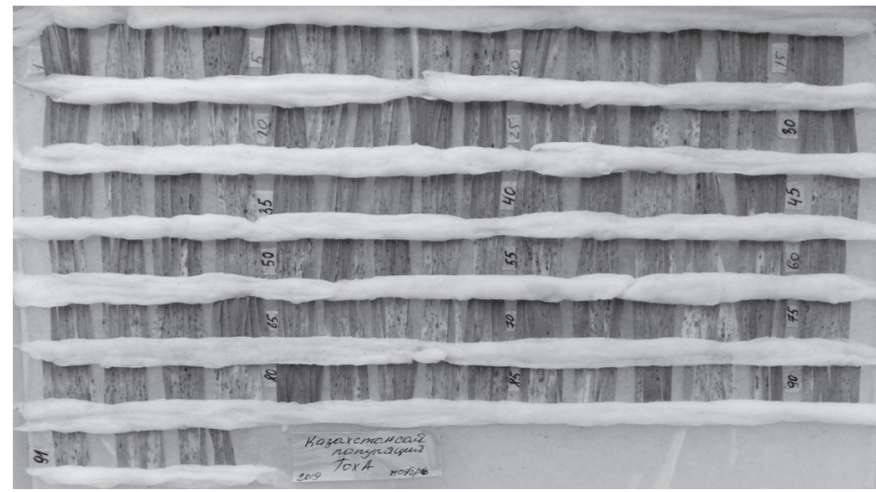

Рисунок. Оценка образцов пшеницы на устойчивость к Ptr ToxA (Казахстанская популяция изолятов).

В результате оценки на устойчивость к Ptr ToxA и Ptr ToxВ было выделено 17 перспективных линий и 5 казахстанских сортов (Dana, Daulet, Diana, Dinara, Krasnovodopadskaya 210) с устойчивым типом реакции на две популяции P. tritici-repentis. Также эти образцы показали высокую фитопатологическую устойчивость в 2019 году к пиренофорозу на естественном инфекционном фоне (п. Алмалыбак, Алматинская область, Казахстан) (таблица 1). Рекомендуется дальнейшее исследование отобранного материала на наличие генов устойчивости Р. tritici-repentis.

\section{Список литературы}

1. Михайлова Л.А., Мироненко Н.В., Коваленко Н.М. Желтая пятнистость пшеницы. Методические указания по изучению популяций возбудителя желтой пятнистости Pyrenophora tritici-repentis и устойчивости сортов. ВИЗР, Санкт-Петербург, $2012,64 \mathrm{c}$.

2. Lamari L., Bernier C.C. Genetics of tan necrosis and extensive chlorosis in tan spot of wheat caused by Pyrenophora tritici-repentis // Phytopathology, 1991, 81, p.1092-1095. 
3. Lamari L., Bernier C.C. Toxin of Pyrenophora tritici-repentis: host specificity, significance in desease and inheritance of host-reaction // Phytopathology, 1989, 79, p.740-744.

4. Кохметова А.М., Кремнева О.Ю., Кейшилов Ж.С., Султанова Н. Ж. Расовый состав и вирулентность изолятов Pyrenophora tritici-repentis в Северо-кавказском регионе России и Республике Казахстан // Eurasian Journal of Applied Biotechnology. 2016. №3. С.57-66.

DOI 10.18699/GPB2020-45

\section{Рост и развитие гибридов астильбы в лесостепи Алтайского края}

Куранда Ю.В., м.н.с.

ФГБНУ Федеральный Алтайский научный цуентр агробиотехнологий, г. Барнаул, Россия.

*e-mail: margo.22@mail.ru

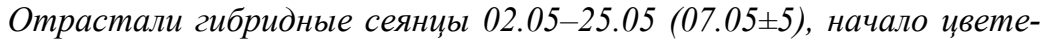

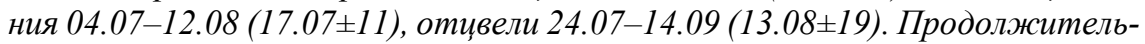
ность ияветения была 12-45 (27士10 дней). Высота гибридов составила 20,0-

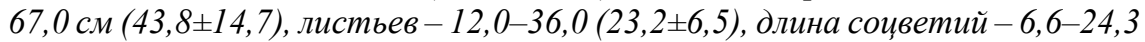

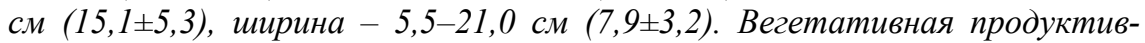
ность популяции сеянцев составила 4-35 (16士8) розеток листьев, генеративная - 1-29 (8土7) ияветоносов.

Ключевье слова: астильба, гибриды, фенология, морфология, продуктивность.

\section{Growth and development of Astilba hybrids in the forest-steppe of the Altai territory}

Kuranda, Yu., Junior researcher, Federal state scientific institution of FANZA, Department NIISS Barnaul, Russia.margo.22@mail.ru

Hybrid seedlings grew on 02.05-25.05 (07.05 \pm 5$)$, the beginning of flowering on 07.07-12.08 (17.07 \pm 11$)$ faded on 07.24-14.09 (13.08 \pm 19$)$. The duration of flowering was 12-45 (27 \pm 10 days). The height of the hybrids was 20.0-

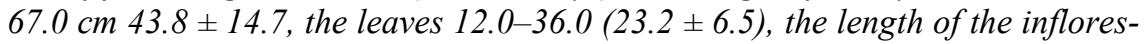
cences was 6.6-24.3 cm (15.1 \pm 5.3$)$, width $-5.5-21.0 \mathrm{~cm}$ (7.9 \pm 3.2$)$. The vegetative productivity of the seedling population was 4-35 (16 \pm 8$)$ rosettes of leaves, generative - 1-29 (8 \pm 7) peduncles.

Key words: astilba, hybrids, phenology, morphology, productivity.

Астильба (Astilbe Buch-Наm.) - род многолетних травянистых растений, популярных в ландшафтной архитектуре. Введена в культуру во II по- 